FACTA UNIVERSITATIS

Series: Architecture and Civil Engineering Vol. 11, No 1, 2013, pp. 13 - 25

DOI: 10.2298/FUACE1301013R

\title{
THERMAL BRIDGES IN BUILDINGS AS A RESULT OF URBAN TRANSFORMATION
}

UDC 728:697:551.524=111

\author{
Aleksandar Rajčić \\ University of Belgrade, The Faculty of Architecture, Serbia \\ rajcic@arh.bg.ac.rs
}

\begin{abstract}
The paper analyzes the deterioration of energy performance in buildings and construction defects caused by thermal bridges resulting from changes taking place in urban planning, for example in Vojvode Stepe street in Belgrade. The transformation of the urban matrix done over the last 50 years coupled with a time lag in implementation, resulting in partial sequences to completed buildings, has left a number of free side walls (gable ends), which are exposed to temperature influences. In some cases, these walls are adequately heat-treated, but in many others (especially in existing buildings) they are not, causing increased heat loss mould growth, leading to construction damage, and health risks to users.

This paper presents a methodology for testing the risk of condensation in a specific example, using the computational support of $T$ Studio software, intended for $2 D$ calculations of thermal bridges, with an emphasis on contact temperature in the interior, relative humidity, and a term that is new to us: Temperature factor.
\end{abstract}

Key words: Thermal bridges, temperature factor, mould, gable wall.

\section{INTRODUCTION}

The processes of urban transformation in cities takes various forms. A common characteristic is the general increase in coverage density according to one of the adopted models that define urban parameters. These processes have multiple consequences, especially in areas where buildings meet, or where the width of a building coincides with the width of a building plot/parcel/site, dominant in narrower parts of urban centres, as well as parts of towns in which the inherited urban matrix is based on a narrow cadastral or building parcels/plots.

Although cases where buildings are in direct contact with adjacent buildings are considered to contribute to energy efficiency, or at least reduce energy losses, the situation in

Received December 22, 2012 
this sense is more complex, primarily bearing in mind the dynamics of construction and time needed for zoning changes to be completely implemented.

\section{LOCATION}

We can discern and analyze these changes from the example of Vojvode Stepe street and its associated land and buildings, in Belgrade.

The street is in the municipality of Voždovac (an urban area) and stretches from Autokomanda to Trošarina, a distance of about $3 \mathrm{~km}$. It is considered to be an important road, the route of GSP city tram and bus traffic, despite the street's lack of a continuous wide profile.

More important for this discussion is the fact that the inherited urban matrix is mainly based on narrow parcels/plots, with widths from $12 \mathrm{~m}$ to $15 \mathrm{~m}$, dating from before World War II, and providing mainly for family houses, or possibly for houses with apartments to rent.

In the period after World War II, certain parts were acquired for constructing multifamily residential buildings, with the consequent enlargement of plots while keeping the building line, despite it being inappropriately close to tram lines (only 2-3m distant).

During the expansion of construction in our country during the 1970 s and ' 80 s, different types of buildings were designed and constructed in the central zone of the street around the church, so that frontages facing the street expanded while building lines retreated, with the first free-standing buildings and skyscrapers appearing. A period of stagnation in the 1990s did not bring significant changes. One might say that only in the new millennium did significant planning, design, and construction activities occur.

What is certainly most visible today is the fact that most buildings now under construction are defined and limited to existing sites i.e. with narrow street fronts, cases of merging plots are almost negligible, and the construction line is drawn 20 meters back from the axis of the street in most locations.

Bearing in mind that urban parameters allow a significant increase in density or coefficient, new buildings have between 6 and 8 storeys above ground, which is significantly different from inherited urban spatial patterns

Since the dynamics of the building process depend on the general state of the economy, a period of stagnation and recession gave rise to certain characteristics and visible problems, not occurring for the first time and not solely limited to this location. This is not therefore characteristic for buildings that were originally planned as urban dwellings constructed in a row (terrace). In some cases the existing row/terrace has been broken, or even completely destroyed. If we analyze the current situation, we can note the following typical stages:

- An existing building $(\mathrm{GF}+1)$ was destroyed in order to create a new one $(\mathrm{GF}+6)$

- The new building has been moved back ten meters, out of respect for new construction lines so that its side walls remain free, while the whole street-facing frontage is filled.

- Existing buildings touching the new building remain with bare side walls; bearing in mind that these existing buildings are mostly pre-war homes, their facades are inadequate from the standpoint of energy conservation.

Due to time factors in the design process, settlement of property issues, as well as the construction process itself, it may happen that the situation which was conceived as temporary is prolonged for much longer, even indefinitely. Thus, for example, some large 
multi-family buildings from the 1960s have remained with exposed bare gables. In view of the period in which they were constructed, their walls of brick are not insulated, and there are no insulated floor structures (Fig. 1).

The following is evident on thermo-vision images:

- Increased heat flow in floor area constructions

- Different modes of heating in a single dwelling, since these buildings are not connected to the city remote central heating system, so that it can be seen that some rooms are heated while others are not.
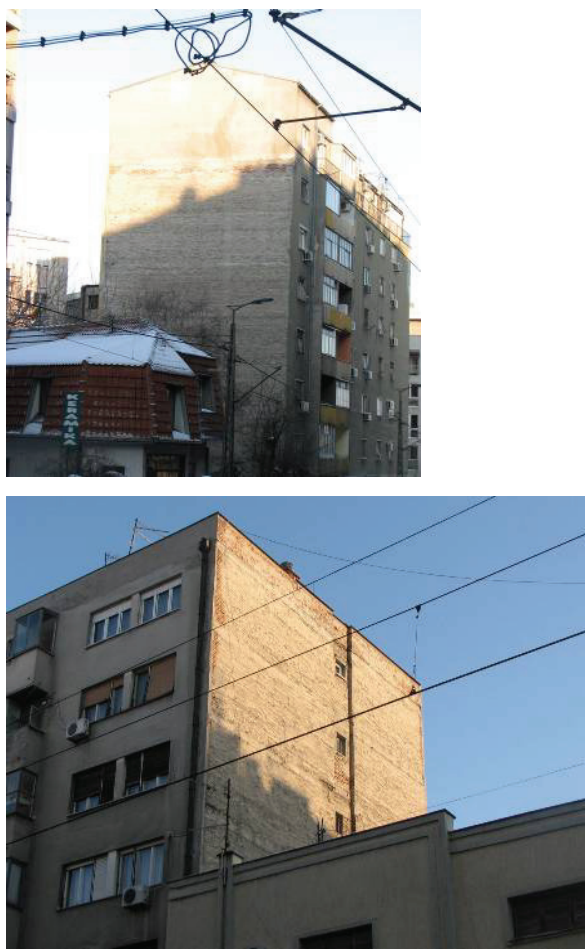
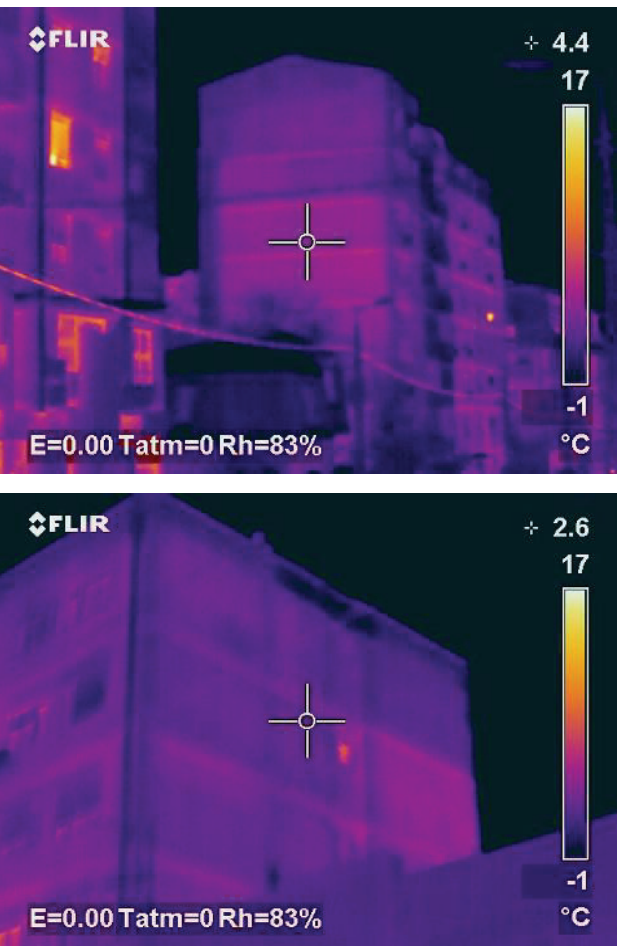

Fig. 1 Examples of free non-insulated side walls of multi-storey apartment buildings

New buildings should be designed and implemented in accordance with current regulations, so that potential problems are minor. However, we should not ignore them, and bear in mind the following:

- Regulations governing the treatment of lateral facades to date in these urban-planning conditions, that is, those touching the side walls of adjacent buildings, relate to "dilatation walls", and their thermal parameters, given in JUS (SRPS) U.J5.600, manifested through the heat transfer coefficient, which is around $10 \%$ higher than the declared coefficient of "normal" facade walls, or in the case of Belgrade and climate zones 2 , the coefficient of the wall between the buildings $\mathrm{k}=1.0 \mathrm{~W} / \mathrm{m}^{2} \mathrm{~K}$, compared to the front facade of coefficients $\mathrm{k}=0.9 \mathrm{~W} / \mathrm{m}^{2} \mathrm{~K}$

- Although these values nowadays are considered insufficient in terms of minimizing thermal losses, treatment of the side (dilatation) of the walls is critical, as well as 
its place in the thermal wrapping of the building. Having regard to the phasing of construction, this position is therefore treated as part of one wrapping with a correction coefficient of value 1 , i.e. the same as the front or rear façade

- In existing buildings, especially houses, exposing the walls to dilatation may result in greater problems than in the new buildings, primarily with the fact that the houses from this period of construction were built with relatively thin gable walls, using $25 \mathrm{~cm}$ thick bricks in residential parts, and $12 \mathrm{~cm}$ thick brick work in the attic, with poorly filled joints

In the analyzed example, the old house from 1937 was left with bare gable walls, because the small adjacent pre-war houses were destroyed and in 2010 a residential building GF +7 was erected (Fig. 2).

During the long period of service, before this urban transformation, problems did not occur in the interior, although a wall made of solid brick, $25 \mathrm{~cm}$ thick, plastered outside with lime mortar, was largely damaged with the passage of time. The floor construction above ground floor is a full reinforced concrete slab, $12 \mathrm{~cm}$ thick.

Although the linear heat loss at the junction of the wall-ceiling is significant, and the facade is not insulated, the interior does not reveal signs of mould, except in exceptional circumstances when the humidity in the room is raised far above normal.

The part of the flat that was sheltered and protected by the old demolished house is the bathroom. In spite of increased relative humidity, due to good natural ventilation, mould never occurred.

After demolition of the old adjacent house, the corresponding side wall is bare, the storey reinforced concrete slab is unprotected out on the facade, and an additional aggravating factor is the non-plastered facade area, with unfilled joints.

During the autumn and winter months, mould occurred in the bathroom, at the junctions of the wall and ceiling and the wall and window (not directly related to the considered connection).

Increased heat losses are illustrated by thermal imaging (Fig. 3), where heat flow in the floor slab zone can be clearly seen.

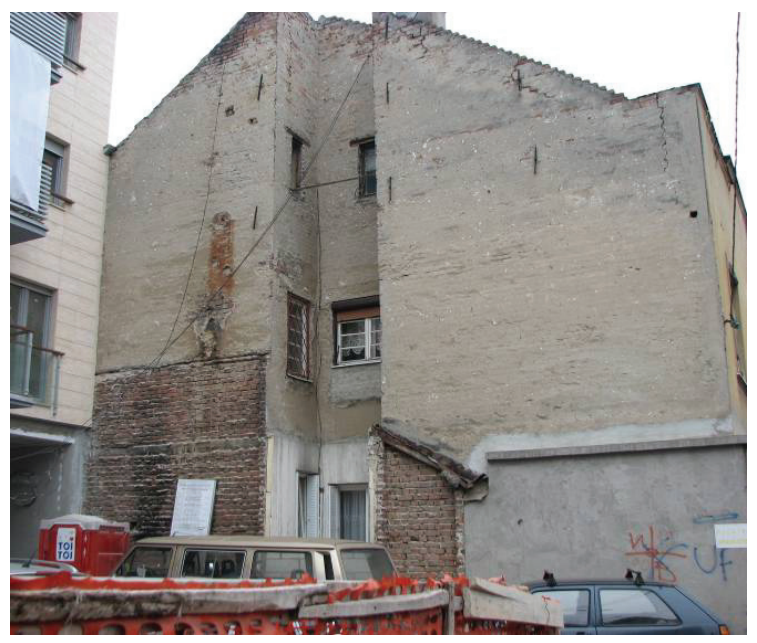

Fig. 2 Side (gable) wall of the old house 


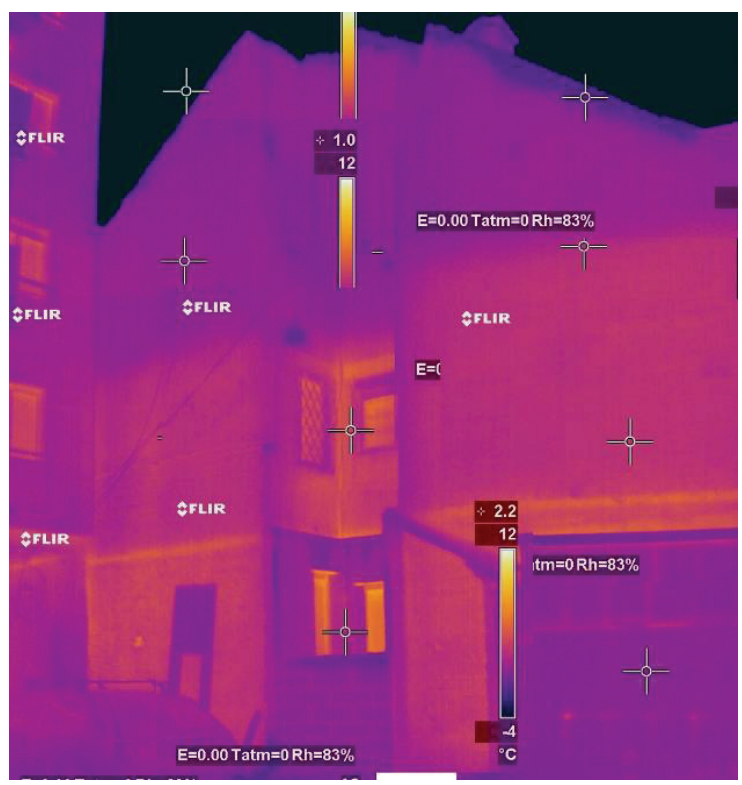

Fig. 3 Thermovision image of side (gable) wall

Due to the impossibility of external intervention, repairs from the inside were accessed, the mould was removed, and anti-fungicidal coating was applied (Pherma white).

This did not yield results, because after 10 days, the anti-fungicidal coating began to flake, and in these parts mould once again formed colonies (Fig. 4), clearly expressed as the result of additional heat flow caused by the thermal bridge (Fig. 5).
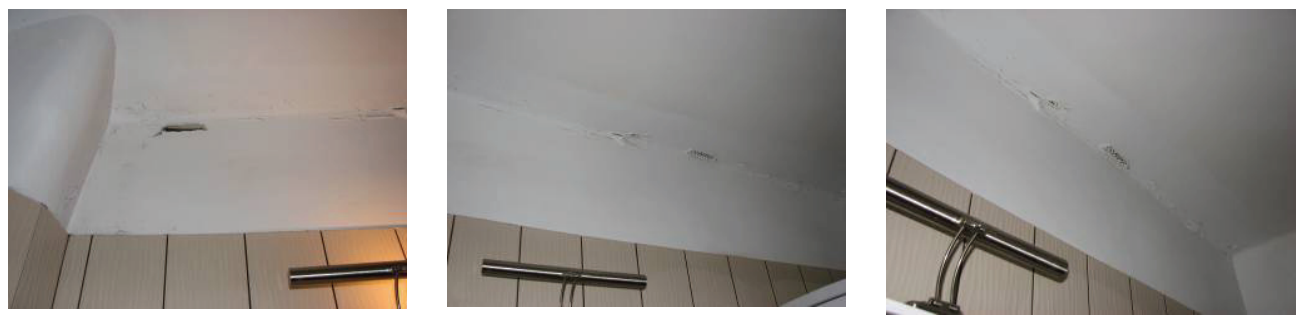

Fig. 4. Photo bathroom interior (junction: wall - ceiling)
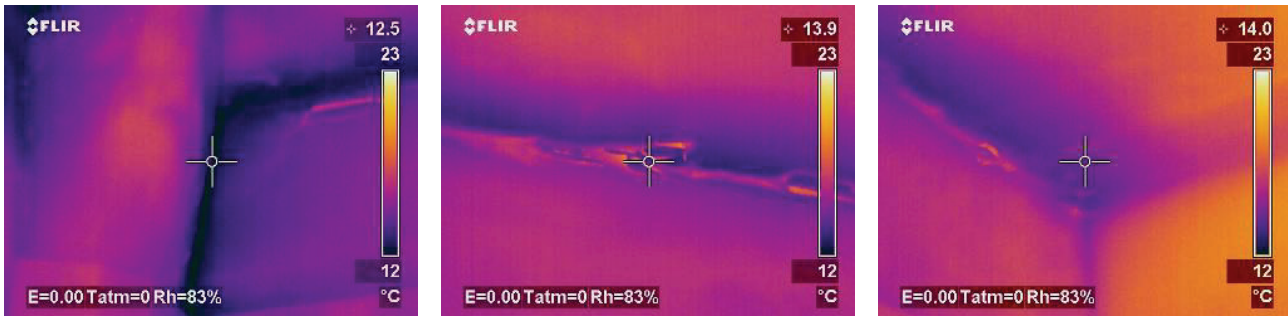

Fig. 5. Termography bathroom interior (junction: wall - ceiling). 


\section{THERMAL ANALYSIS}

Junctions of this type are covered in the regulations and by the current national standard (SRPS.U.J5.510), and in case 24.1, while linear thermal loss is given with formula:

$$
k \mathrm{l}=(0.4 * d 1) /((d 2 / \lambda 1)+0.15)
$$

where:

$d 1$ The thickness of the floor structure (slab)

$d 2$ The thickness of the solid façade wall

$\lambda 1$ The coefficient of thermal conductivity of floor structure (slab)

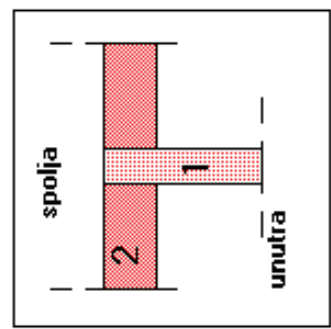

Thin layers of the facade and floor structure were ignored in this case.

The EU legislation, thermal bridges are treated in several ways, as defined in national legislation. However, there may be distinguished the following cases:

- Thermal bridges are given in tabular values, which are based on a typical cases, and where the real structure does not affect the calculated, or adopted values, as given for example in EN14683, that is applied in most EU countries

- Thermal bridges are related to tabular values, which are parametrically dependent on of the input data, such as, for example, in Switzerland [6]

- Thermal bridges are calculated in detail, in accordance with EN10211-1 and EN102011-2, which defines procedures for two-and three-dimensional calculations of heat losses

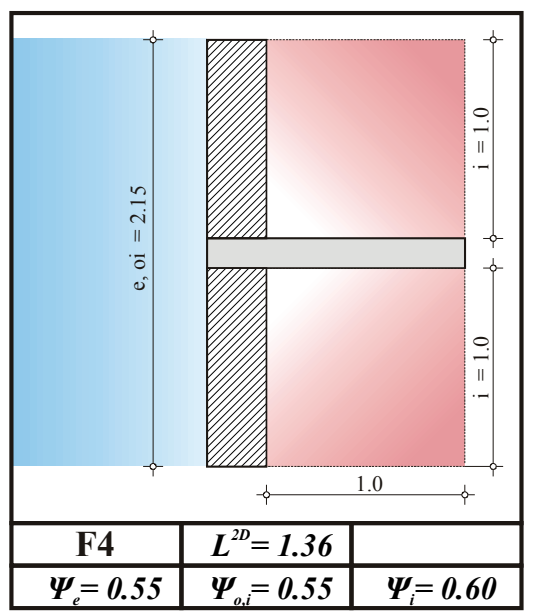

The presented problem, i.e. architectural detail, cannot be easily harmonized with these regulations because:

- In cases of treatments in accordance with EN14683, the legislator did not foresee the possibility of not isolating the façade wall, except in cases where the wall is made of gas concrete blocks, which is not the case here, and cannot therefore be taken into consideration (Fig 6). 
- German and Swiss regulations do not treat the junction of floor structure with non insulated facade walls, because this is not in accordance with national legislation

The only way to specifically determine linear thermal losses is by using mathematical procedures that are subject to validation in accordance with EN10211-1 and EN102011-2.

The main difference from the calculation procedure valid so far, which was based on prescribed formulas and expressions, is the fact that these are not given in standards, whereas both input and output data for the four test cases are defined i.e. results to be obtained, so that the tool or software that was used for the calculation can be considered valid.

It must be noted that the level of recognition of problems and the level of accuracy manifested through the two-dimensional approach or two-dimensional calculations satisfy most of the problems, while the three-dimensional approach, or three-dimensional calculation, is intended for solving more complex problems.

In this sense, the aforementioned test cases are classified, the first two test cases concerning $2 \mathrm{D}$ issues, and the other two $3 \mathrm{D}$ issues.

\section{NUMERICAL SimULATION}

For the analysis of the mentioned problems, the authors' TStudio software was used, designed and developed for 2D calculations, using $\mathrm{FDM}^{1}[13]$ :.

The calculation was made on a geometric model corresponding to the model in EN 14683 , where the main features of the internal length of the façade wall of the intercept is $1 \mathrm{~m}$, and the intercept length of floor slabs is also $1 \mathrm{~m}$.

In this case, the heterogeneity of the brick wall in mortar is approximated by a quasihomogeneous material, whose coefficient of heat conduction is $\lambda=0.64 \mathrm{~W} / \mathrm{mK}$. The coefficient of thermal conductivity of reinforced concrete slabs, $12 \mathrm{~cm}$ thick, was approved with $\lambda=2.33 \mathrm{~W} / \mathrm{mK}$.

Thin layers of facade treatment, as well as floor and ceiling structures, are not taken into consideration, in accordance with the methodology of EN14683.

For the condensation issue, in this case manifested by mould or damage to the interior construction, three factors are crucial:

- Internal surface temperature, or contact temperature

- relative humidity in the interior

- air temperature in the interior.

In the analyzed case, following input data were adopted:

- Indoor design temperature and air temperature in the interior was $20{ }^{\circ} \mathrm{C}$

- External design temperature was variable, and was adopted with the following values: $-18,-12,-5$ and $0{ }^{\circ} \mathrm{C}$

- The thickness of the reinforced concrete floor slab is variable and was adopted with the following values: 12,16 and $20 \mathrm{~cm}$, and thin layers of floor and ceiling were not taken into account

- The thickness of the side wall is constant, $25 \mathrm{~cm}$ bricks in mortar, and layer thickness (coating) were not taken into account.

\footnotetext{
${ }^{1}$ Finity Difference Method
} 
The calculated values are presented in table (Table 1), or in chart (Fig. 6).

Table 1. Internal surface temperatures at the junction wall - slab

\begin{tabular}{|c|c|c|c|c|c|c|c|c|c|}
\hline \multirow[b]{3}{*}{ Slab thickness } & & \multicolumn{8}{|c|}{ External design temperature $(\mathrm{Te})$} \\
\hline & & \multicolumn{2}{|c|}{$-18^{\circ} \mathrm{C}$} & \multicolumn{2}{|c|}{$-12^{\circ} \mathrm{C}$} & \multicolumn{2}{|c|}{$-5^{\circ} \mathrm{C}$} & \multicolumn{2}{|c|}{$0^{\circ} \mathrm{C}$} \\
\hline & & $\min$ & $\max$ & $\min$ & $\max$ & $\min$ & $\max$ & $\min$ & $\max$ \\
\hline & $12 \mathrm{~cm}$ & 9.30 & 10.6 & 10.97 & 11.73 & 12.94 & 13.54 & 14.35 & 14.83 \\
\hline & $16 \mathrm{~cm}$ & 8.66 & 9.89 & 10.71 & 11.66 & 12.55 & 13.35 & 14.01 & 14.66 \\
\hline & $20 \mathrm{~cm}$ & 8.13 & 9.61 & 10.00 & 11.25 & 12.20 & 13.17 & 13.72 & 14.61 \\
\hline No sl & impact & \multicolumn{2}{|c|}{10.66} & \multicolumn{2}{|c|}{12.12} & \multicolumn{2}{|c|}{13.85} & \multicolumn{2}{|c|}{15.07} \\
\hline
\end{tabular}

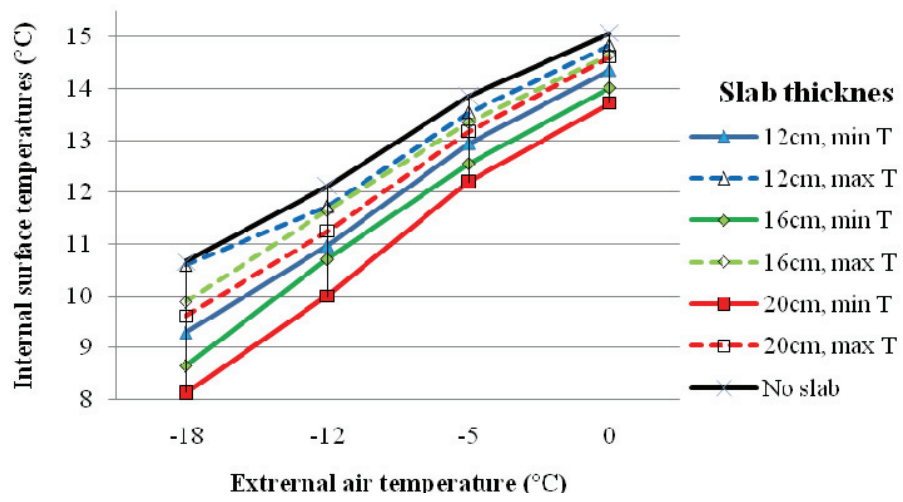

Fig. 6 Chart of internal surface temperatures at the junction wall - slab

The calculated internal surface temperatures refer to the zone of direct connection the wall-slab, with a width of $5 \mathrm{~cm}$ from the corner, and are thus represented in a range from minimum (minT) to maximum (maxT), whereby we can note the following rule: the contact temperature decreases as the corner, or junction is approached

It is also noticeable that the temperature decreases with the increasing thickness of floor slabs, increasing the impact of heat loss due to the effect of the thermal bridge.

Furthermore, the internal surface temperatures are directly proportional to the external air temperature, with linear-approximate dependence.

Overall, for the analyzed case, values that were calculated by the TStudio program, ranging from $9.3^{\circ} \mathrm{C}$, for the corner, to $10.6^{\circ} \mathrm{C}$, at the distance of $5 \mathrm{~cm}$ from the corner, where the indoor air temperature was $20{ }^{\circ} \mathrm{C}$, and the outdoor air temperature was $-18{ }^{\circ} \mathrm{C}$. Such a low outdoor temperature was recorded by current standards, as well as outdoor design temperature for the second climatic zone, i.e. for Belgrade. Bearing in mind that usual winter temperatures are not so low (average about $5.6^{\circ} \mathrm{C}$ in Belgrade) calculated values of internal surface temperatures were in this case between $10.97{ }^{\circ} \mathrm{C}$ and $11.73{ }^{\circ} \mathrm{C}$.

Most realistic values are obtained by adopting the external design temperature of $-5^{\circ} \mathrm{C}$, in which case calculated internal surface temperatures are between $12.94^{\circ} \mathrm{C}$ and $13: 54{ }^{\circ} \mathrm{C}$.

In all analyzed cases, it is apparent that variation from the temperatures were calculated without the influence of floor slabs, therefore as one-dimensional heat conduction. 
This difference varies between approximately $1.5^{\circ} \mathrm{C}$ and $2.5^{\circ} \mathrm{C}$, and is proportional to the thickness of floor slabs and the temperature difference of indoor and outdoor air. The relatively small difference of only a few degrees can be explained by the fact that the wall is completely non insulated.

Calculated temperature distribution in this case is presented in figure (Fig. 7).

Calculated heat flux distribution is given in figure (Fig. 8), and there is a noticeably enhanced heat flow through the floor slab.

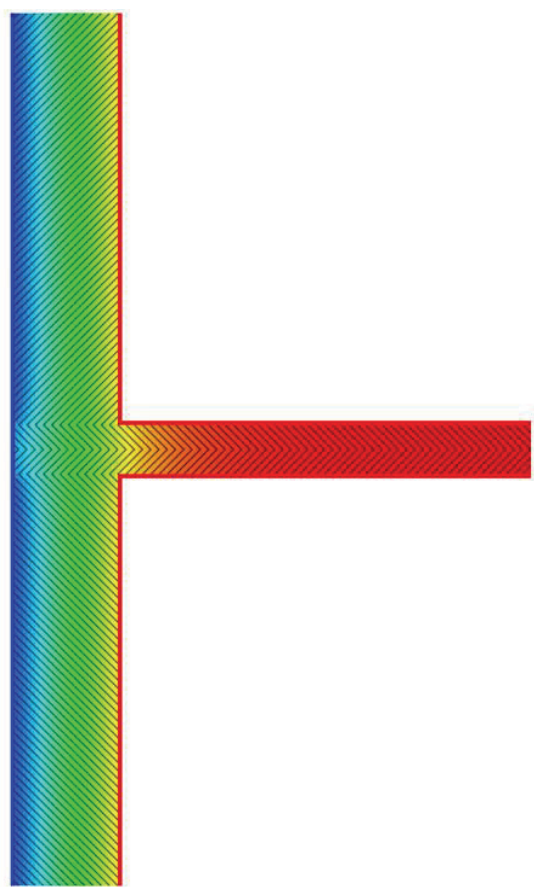

Fig. 7: Temperature distribution in the analyzed detail

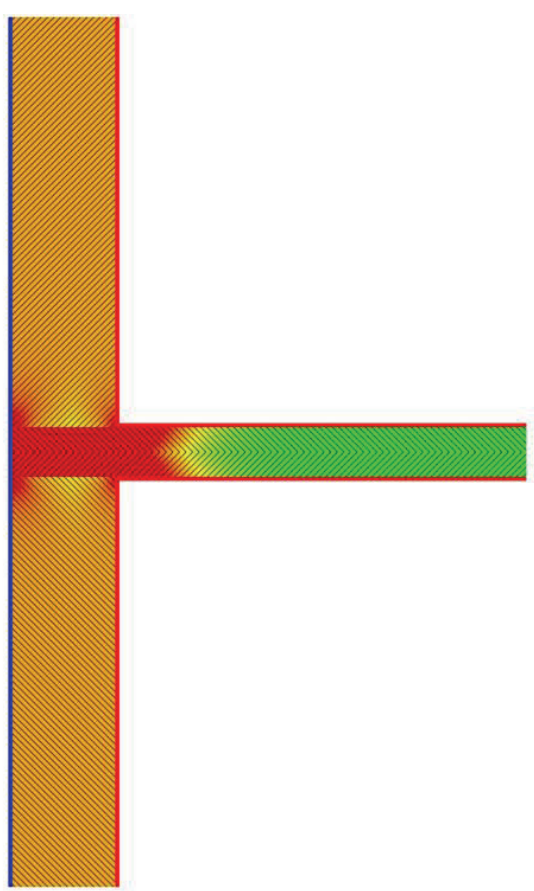

Fig. 8: The heat flux in the analyzed detail

Due to the large number of different temperature relationships, risk assessment of condensation, and therefore of mould, was performed with the procedure that is new in domestic theory and practice, and refers to the temperature factor

\section{TEMPERATURE FACTOR}

Temperature factor at the steady state conditions can be expressed by the formula [16]:

where:

$$
f_{R s i}=\left(T_{s i}-T_{e}\right) /\left(T_{i}-T_{e}\right)
$$

$T s i$ is surface internal temperature,

$T i$ is the temperature of the internal environment

$T e$ is the temperature of the external environment 
Temperature factor fRsi depends only on the structure. Once calculated for certain values of $T i$ and $T e$, can be used to calculate the surface temperature under different conditions, using the formula:

$$
T_{s i}=T_{e}+f_{R s i}\left(T_{i}-T_{e}\right)
$$

In order to prevent the formation of mould, it is necessary to fulfill the condition that every point on the inner surface has a temperature or temperature factor greater than or equal to critical. This condition therefore depends on the external temperature, the internal air temperature, and the relative humidity of indoor air.

Correlation of these parameters can is expressed [14]:

$$
f_{R S i} \geq\left(\left(0.0125^{*} \phi\right)^{0.1247} *\left(109.8+T_{i}\right)-109.8-T_{e}\right) /\left(T_{i}-T_{e}\right)
$$

where

$\phi$ is relative humidity of indoor air (\%)

$\mathrm{T}_{\mathrm{i}}$ is internal air temperature $\left({ }^{\circ} \mathrm{C}\right)$

$\mathrm{T}_{\mathrm{e}}$ is external air temperature $\left({ }^{\circ} \mathrm{C}\right)$

This interdependence is shown as a chart, for winter conditions in Serbia, compared to projected relative humidity in the room (Fig. 9) [13].

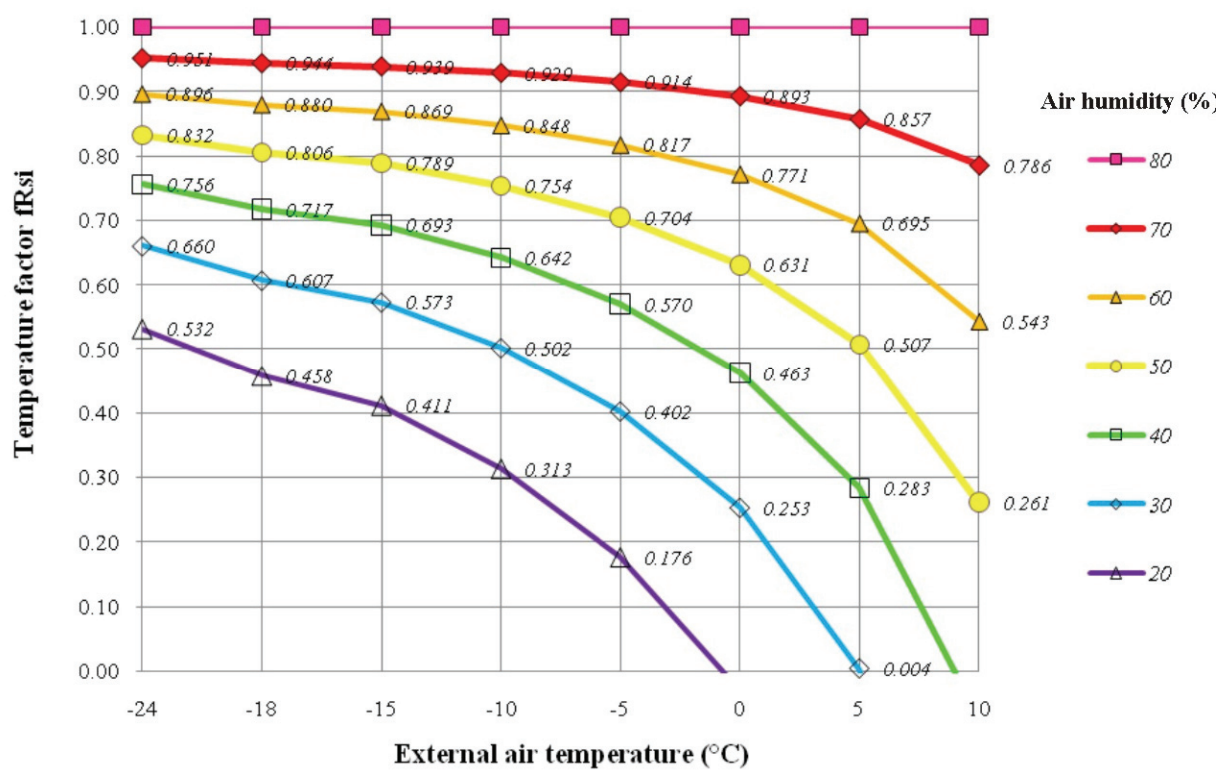

Fig. 9 Temperature factor fRsi required to prevent the occurrence of mold, depending on the external air temperature and relative humidity of indoor air $\varphi(\%)$, the internal temperature of $20^{\circ} \mathrm{C}$ [13]: 
As the relative humidity of indoor air is a category that depends on the purpose of the space, and the water vapour created relates to activities performed in the space (on the one hand) and the manner and intensity of ventilation (on the other hand), a wide range of potential percent-relative humidity comes into consideration. In calculating tests we usually take a value of $50 \%$.

In the analyzed case, keeping in mind that condensation and mould formation occurred in the bathroom, where the relative humidity is often maximum, the relative humidity of indoor air can be taken into consideration with a value of $70 \%$.

This provides the values of temperature factors, which ranges from 0.89 to 0.94 , therefore average 0.9 , for winter conditions in Belgrade, and adopted relative humidity of the indoor air of $70 \%$.

In the case of low relative humidity, such as the for example in the rooms, from about $50 \%$, values of temperature factors are from 0.63 to 0.81 under the same conditions. The average value is therefore 0.7 , which actually significantly reduces the real danger of mould formation.

\section{CONCLUSION}

The processes of urban transformation, analyzed here on the example of real events in Vojvode Stepe street in Belgrade, which resulted from the expansion of the street front and the shifting back of the new building from the existing structure, carries with it certain consequences. It is undisputed that from an urban aspect the wider street profile is better than the narrower profile. However, in the present situation, it is not possible to consistently implement the planned expansion which the regulatory plan for Vojvode Stepe street established, mainly because several groups of high, or sufficiently large buildings cannot be realistically demolished.

In other streets, the process of "displacement" of the street front to create a building has been slow, with a time lag, which led to the analyzed problem of exposing side (gable) walls of both new and existing buildings

New buildings must be designed and constructed so that their thermal characteristics are in accordance with regulations, so that side walls are generally insulated.

In this case, the problem is only reduced by increasing the real area of the building plot/parcel envelope, except in cases where after the new building is finished, the adjacent parcel contains a demolished old building and the new building cannot be built within a reasonable time, leaving part of the side walls not insulated or unprotected, where none of the parties involved assume the obligation to address this problem. It must be noted that existing domestic regulations do not recognize this as a real problem, nor do urban conditions define which one of the participants has an obligation to isolate the exposed side walls.

A bigger problem occurs in situations where a new building, with withdrawn regulation, is left open. The side (gable) wall of the old, existing building is often damaged, with construction damage in the interior of the old house, as in this case. It is evident that the only suitable rehabilitation would be placing external thermal insulation onto the threatened area, usually the entire gable wall, which raises the question of who should finance this work. 
In a number of cases, diligent investors of a new building try to solve this problem, primarily in order to regulate and refine their immediate surrounding. In other cases, unscrupulous investors of the new facility, refuse any effort to solve this problem, not recognizing their interest in this new situation. Then the burden of necessary works shifts to the owners or users of the existing (old) building, who were through no fault of their own brought into the problematic situation. In extreme cases, such as is presented here, very unscrupulous investors filed complaints with the competent authority building inspection, requiring owners of the old building to repair side walls of the existing facility at their own expense!

From a technical point of view, this paper shows that in analyzed situations, low surface interior temperatures, which are most critical in the junction of the wall - floor (ceiling), are due to the influence of a thermal bridge, combined with a increased relative humidity of indoor air, resulting in condensation in certain critical areas, the development of mould, and construction damage as well as deteriorating microbiological terms of use.

The solution of such problems is not possible from the interior side. This is mainly because problems like this are manifested in bathrooms, which are usually the smallest room in the apartment, and any construction of intervention on the inside, in the form of internal insulation and inner lining, is out of the question, simply because there is no room for it. Also, the application of anti condensation and anti fungicidal paints and coatings has no lasting effect, only lasting two weeks in the present case. The problem can be relatively successfully controlled by intensive natural ventilation, but such activity is also controversial in winter, because of the need for heating.

The only correct and durable construction intervention, in this case, is the application of external thermal insulation, with adequate protection of the facade, which actually causes new problems (stated above).

\section{REFERENCES}

1. УС (СРПС) У.J5.510: Методе прорачуна коефицијената пролаза топлоте у зградама

2. JУС (СРПС) У.J5.600: Tehnički uslovi za projektovanje i gradjenje zgrada

3. EN ISO 14683: Thermal bridges in building constructions. Linear thermal transmittance. Simplified methods and default values

4. EN ISO 10211-1: Thermal bridges in building constructions. Heat flows and surface temperatures. Part 1: General calculation methods

5. EN ISO 10211-2: Thermal bridges in building constructions. Calculation of heat flows and surface temperatures. Part 2: Linear thermal bridges

6. CATALOGUE DES PONTS THERMIQUES. (2003.). Berne: Office fédéral de l'énergie.

7. Akander, J. (2000.). The ORC-Method - Effective Modelling of Thermal Performance of Multilayer Building Components. Doctoral thesis. Stockholm, Sweden: The Royal Institute of Technology

8. Blomberg, T. (1996.). Heat conduction in two and three dimensions - Computer Modelling of Building Physics Applications. Lund University, Sweden

9. Claesson, J. (2002). Dynamic Thermal Networks. Background studies I: Elements of a mathematical theory of thermal responses. Chalmers Technical University, Dept. of Building Physics, Gothenburg, Sweden

10. Feist, W. (2004). Wärmebrücken. Wiesbaden: Hessisches Ministerium füf Wirtshaft

11. Hong, C.-P. (2004). Computer modeling of heat and fluid flow in materials processing. Bristol and Phyladelphia: Institute of Physics Publishing

12. Larbi, A. (2005). Statistical modelling of heat transfer for thermal bridges of buidings. Energy and buidings, 37 
13. Rajčič, A. (2011.). Metode projektovanja i simulacije termičkih mostova u arhitektonskim objektima. Doktorska teza, Arhitektonski fakultet Univerziteta u Beogradu, Srbija

14. Viliems, V., Shield, K., \& Dinter, S. (2006.). Gradjevinska fizika. Gradjevinska knjiga, Beograd

15. Tilmans, A., \& Orshoven, D. V. (2010). Software and atlases for evaluating. Belgian Building Research Institute (BBRI), Belgium

16. Ward, T., \& Sanders, C. (2007). Conventions for calculating linear thermal transmittance and temperature factors. Glazgow, Scotland: BRE PRESS

17. Wouters, P., Schietecat, J., \& Standaert, P. (2003). Practical guide for the hygrothermal evaluation of thermal bridges. Eurokobra.

\title{
TERMIČKI MOSTOVI U ZGRADAMA KAO POSLEDICA URBANISTIČKIH TRANSFORMACIJA
}

\begin{abstract}
Aleksandar Rajčić
U radu se analizira pogoršanje energetskih performansi zgrada, kao i gradjevinska oštećenja koja su nastala usled dejstva termičkih mostova, a kao posledica nekih od promena koje se odvijaju u urbanizmu, na primeru ulice Vojvode Stepe u Beogradu. Transformacija urbane matrice koja se odigrava poslednjih 50 godina, a naročito danas, spregnuta sa vremenskim pomakom u realizaciji, rezultuje delimično kompletiranim nizovima zgrada, sa brojnim slobodnim bočnim zidovima (zabatima), koji su eksponirani temperaturnim uticajima. U nekim slučajevima, ove pozicije su na adekvatan način termički tretirane, a u brojnim slučajevima, koji su naročito prisutni kod postojećih zgrada nisu, te su to mesta gde su pojačani toplotni gubici, $i$ zone u kojima se odvija razvoj budji, koji vodi gradjevinskim štetama i zdravstvenim rizicima po korisnke.

U radu se prezentuje metodologija provere rizika od kondezacije, na konkretnom primeru, uz računsku podršku autorskog softvera TStudio, namenjenog za $2 D$ proračune termičkih mostova, sa naročitim osvrtom na kontaktne temperature u enterijeru, relativnu vlažnost vazduha i pojam koji je nov u nas: temperaturni faktor.
\end{abstract}

Ključne reči: Termički mostovi, temperaturni faktor, budj, zabatni zid. 